\title{
Ehlers-Danlos Syndrome, Type I
}

National Cancer Institute

\section{Source}

National Cancer Institute. Ehlers-Danlos Syndrome, Type I. NCI Thesaurus. Code C125696.

Ehlers-Danlos syndrome, type I belongs to the classical type Ehlers-Danlos syndrome. It results most often from mutations in either the COL5A1 gene or the COL5A2 gene. 